\title{
Evaluation of alpha diversity results in the Kargı and Karpuz River basins by SHE analysis
}

\author{
Seda AKKURT GÜMÜŞ ${ }^{* 1}$, Serkan GÜLSOY ${ }^{2}$, Meral AVCI ${ }^{3}$ \\ ORCID: 0000-0001-7879-8460; 0000-0003-2011-8324; 0000-0003-4367-3021 \\ ${ }^{1}$ Manisa Celal Bayar University, 45140 Manisa, Turkey \\ ${ }^{2}$ Isparta Applied Sciences University, 32200 Isparta, Turkey \\ ${ }^{3}$ Istanbul University, 34452 Istanbul, Turkey
}

\begin{abstract}
Turkey, which has richer biodiversity than many surrounding countries, takes some measures at the national and international level to carry this feature to the future in a sustainable way. Conservation of biodiversity is to determine the prominent areas in this regard and the determination of species diversity at a local scale depends on scientific studies. One of the biodiversity levels, alpha species diversity provides the information necessary for the conservation of any area, however, it is also very important to know the sensitivity of habitats to external factors. By determining the balance and sensitivity of ecosystems, the conservation concept can be addressed from a holistic perspective by determining the areas where species are distributed in a balanced way as well as biodiversity. In this study, by applying SHE analysis to the alpha diversity values of Karg1 and Karpuz Stream valleys, the species richness and Shannon alpha diversity values of the areas, as well as the balance and sensitivity of the species within the community, were investigated. As a result, by adding the number of individuals and their distribution in the sample areas to the plant species diversity data, the regions that should be given priority in protection in these valleys were determined.
\end{abstract}

Keywords: SHE analysis, biodiversity, ecosystem balance, habitat sensitivity

\section{Kargı ve Karpuz Çayı Vadilerinde SHE analizi ile alfa çeşitlilik sonuçlarının değerlendirilmesi}

\section{Özet}

Çevresindeki birçok ülkeden daha zengin biyoçeşitliliğe sahip olan Türkiye, bu özelliğini sürdürülebilir bir şekilde geleceğe taşımak için ulusal ve uluslararası düzeyde bazı tedbirler almaktadır. Biyoçeşitliliğin korunması bu konuda öne çıkan sahaların belirlenmesine; yerel ölçekte tür çeşitliliğinin tespit edilmesi ise bilimsel çalışmalara bağlıdır. Biyoçeşitlilik düzeylerinden biri olan alfa tür çeşitliliği herhangi bir alanın korunması için gereken bilgiyi vermektedir; ancak habitatların dış etmenlere karşı hassasiyet durumlarını bilmek de oldukça önemlidir. Ekosistemlerin dengeliliği ve hassasiyetinin tespitiyle biyoçeşitliliğin yanı sıra türlerin dengeli dağ 1 ldığı alanlar belirlenerek koruma kavramı bütüncül bir bakış açısıyla ele alınabilmektedir. Bu çalışmada Kargı ve Karpuz Çayı vadileri alfa çeşitlilik değerlerine SHE analizi uygulanarak, alanların tür zenginliği ve Shannon alfa çeşitlilik değerlerinin yanında türlerin toplum içerisindeki dengelilik ve hassasiyeti de ortaya konmuştur. Sonuçta bitki tür çeşitliliği verilerine birey sayısı ve örnek alanlardaki dağılışları da eklenerek bahsi geçen vadilerde korumada öncelik verilmesi gereken bölgeler saptanmaya çalışılmıştır.

Anahtar kelimeler: SHE analizi, biyoçeşitlilik, ekosistem dengeliliği, habitat hassasiyeti

\section{Introduction}

Different diversity calculation and estimation methods are used to understand the development and dynamics of biodiversity. In revealing biodiversity in any region, the most common methods are alpha, beta, and gamma diversity

\footnotetext{
* Corresponding author / Haberleşmeden sorumlu yazar: Tel.: +905418011753; Fax.: +905418011753; E-mail:sedaakkurtgumus@ gmail.com

(C) Copyright 2021 by Biological Diversity and Conservation $\quad$ Received:01.07.2021; Published: 15.08.2021 BioDiCon. 959626
} 
calculations. For such research, it is very important to create field inventories, analyze the collected information and make the analyzes applicable to conservation problems. The provision of appropriate base data for the purpose and the selection of the index to be applied are other factors to be considered during the process [15, 16, 3, 10, 23, 1, 2].

In this study, habitat sensitivity and stability were determined by applying a combined analysis to the alpha $(\alpha)$ diversity index of Karg1 Stream and Karpuz Stream valleys. This approach, referred to as 'SHE analysis', is a computational method using alpha diversity results that has an important place in biodiversity studies. In the SHE analysis, $S$ means species richness, $H$ is the Shannon-Wiener index, and $E$ represents the results of Buzas and Gibson equation. The $E$ value is also called the balance and equilibrium value of the distribution between species within the community. Sample areas where diversity and stability are high in the SHE analysis constitute important areas in terms of biodiversity. In an ecosystem, not only the abundance of species richness, but also the balanced distribution of species within the ecosystem should be taken into account [23]. For instance, if the species richness is equal in two communities having the same number of species, but the values such as the degree of coverage, abundance or frequency of the species in this community are different, a diversity index value such as Shannon-Wiener $\left(H^{\prime}\right)$ or equality $(E)$ values will be different for these communities. When the proportional or numerical values of the species are different from each other (for instance, 30 individuals from the A species, 2 each from the B and C species), the equality in the community is broken. In such a community, the probability of rare or sensitive species may be high. Thus, interspecies solidarity may be weak and the ecosystem may be sensitive to external threats. Another point to be considered is that the balance should be sought in the same plant layer. For instance, for the case of a Cyclamen sp. and a Pinus sp. it is not possible for individuals to create an evenness between each other. Therefore, equilibrium must be calculated between species of the same physiological type $[7,8,23,1]$. The logic of SHE analysis is different from most other techniques. Initially, most methods (i.e. cluster analysis) calculate similarity or difference measures for all possible sample pairs. In SHE analysis, on the other hand, if the sample set comes from the same statistical distribution, it results in a linear model. Deviation from this linearity indicates a statistical change in community structure and/or species composition, hence the presence of a different community [22]. The basis of SHE is the linear decomposition equation; $H=\ln S+\ln E$. This equation ensures that species richness $\left(S=\right.$ number of species) and equivalence $\left[E=e^{H} / S\right]$ decompose within the same system. Species contributing to Shannon-Wiener $\left(H^{\prime}\right)$ diversity values in pure forest communities may have very high proportional or abundance values. However, when evaluated in terms of ecosystem, these forests are sensitive to threats from outside, since the species richness is low, and the community is represented by a small number of species with high abundance rates in general. Therefore, areas with high species diversity and high stability should be considered as stronger ecosystems on a conservation scale. When the subject is considered within the scope of this information, thanks to the SHE analysis, which provides the opportunity to evaluate the important diversity components together, the stability levels of the sample areas and sensitive habitats are determined, and a new contribution and perspective is provided to the results of the alpha diversity analysis, contributing to the determination of priority protected areas. From this perspective, the study aims to determine the alpha diversity values of Karg1 and Karpuz Stream valleys, which are important in terms of biodiversity, by SHE analysis method.

\section{Materials and Methods}

Karg1 Stream valley is a deep river valley located in east of Antalya Gulf. Originating from Akdağ in the north, this river flows east-west up to the upper ground; from here it is oriented north-south. On the upper slopes, coniferous forests with red pine density and black pine individuals are replaced by shrubs and herbaceous taxa in the valleys. This valley, which is very important in terms of plant diversity, is accepted as an Important Plant Area and an Important Natural Area $[12,17]$. The Karpuz Stream valley, located approximately $25 \mathrm{~km}$ west of the Karg1 Stream valley, is similarly covered with red pine forests on the upper slopes and various plants that grow in different habitats in the valley. In the regions where the flow rate is relatively low, shrub and herbaceous plant taxa are dense. For the biodiversity analysis carried out in these two valleys, 175 different plant species were identified from a total of 160 sample areas with a width of 10x10 meters and 80 per each valley (Figure 1). Species richness values and Shannon-Wiener index values determined for each sample area with the obtained data were used to find the $E$ value in the SHE analysis, that is, to calculate the balance and equality of the sample areas. 


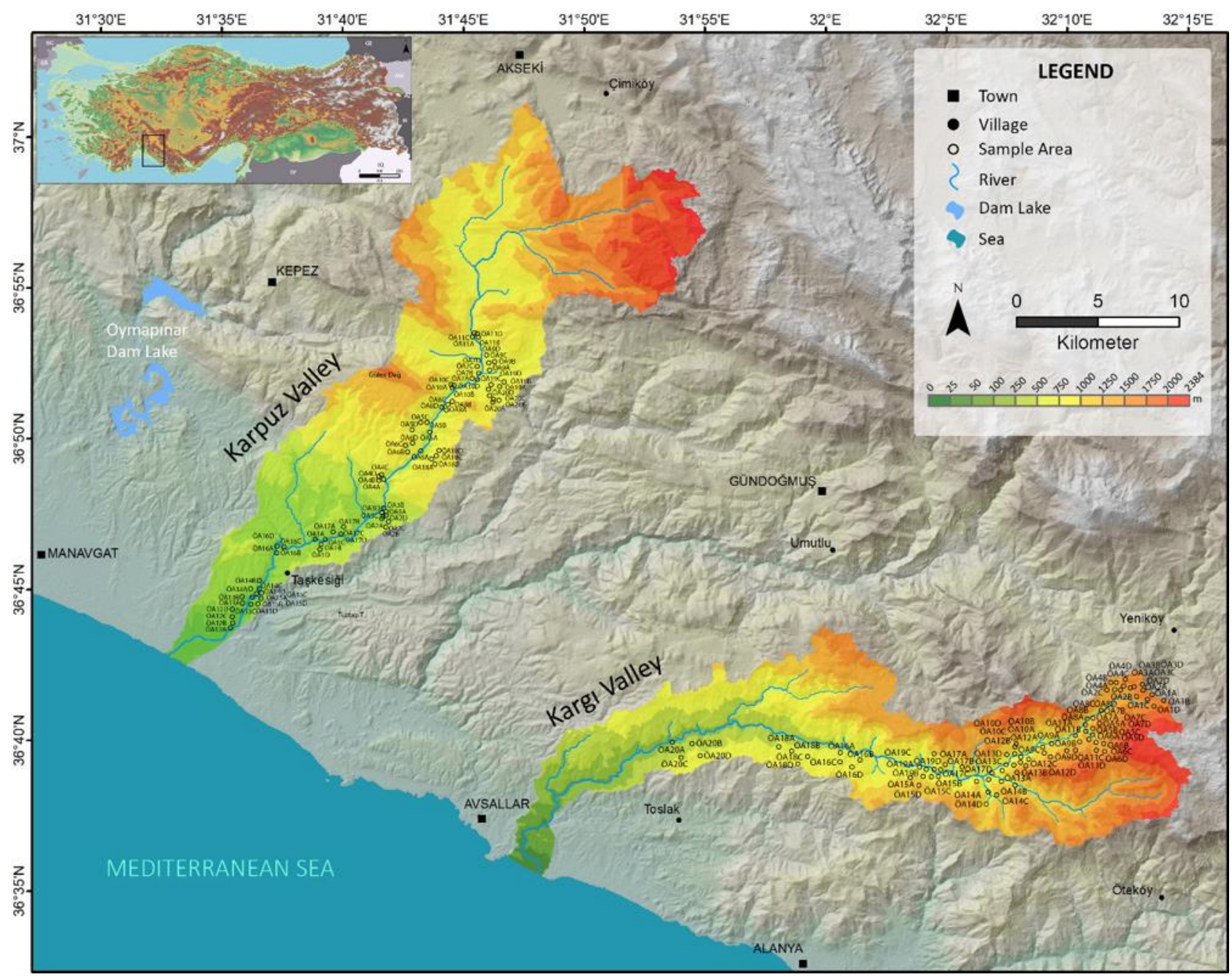

Figure 1: Locations of river valleys and sample areas

Shannon-Wiener index is based on the rationale that the diversity, or information, in a natural system can be measured in a similar way to the information contained in a code or a message. It assumes that individuals are randomly sampled from an infinitely large community and that all species are represented in the sample. Despite its popularity, the use of the Shannon-Wiener index needs much stronger justification. Given its sensitivity to sample size there appear to be few reasons for choosing it over species richness. However, the Shannon-Wiener index seems likely to persist, since many long-term investigations have chosen it as their benchmark measure of biological diversity [19]. With the SHE analysis, one of the problems with the Shannon-Wiener index has been eliminated. This problem could be the result of an increase in the index in the interpretation of greater richness, or greater evenness, or indeed both. However, Buzas and Hayek realized that this can be turned on advantage $[6,13]$. The most obvious advantage of the SHE analysis is that it allows the researcher to interpret changes in diversity [19].

SHE analysis is a set of generalized methodological procedures developed for the study of multi-species population structures. In the SHE analysis, species richness, $S$, is calculated by the presence of plant species in the sample area. The number of different species present in the sample areas represents the species richness. If a species is not present in any sample area, it is not considered in the calculation. In this way, after excluding the non-existent species in the sample areas from the calculation, the remaining number gives the species richness. For instance, in the example showing the calculation stages given in Table 1, 14 different species in the first column represents the species richness for this community.

For the $H$ value, the Shannon-Wiener index and the diversity value of each sample area are found. At this stage, the abundance values $\left(\overline{x_{i}}\right)$ are divided by the total number of individuals $(N)$, and the $\overline{p_{i}}$ value is obtained as a result. This process is done for all species one by one. It is important to obtain the $\bar{p}_{i}$ value. Because in the formula the $\overline{p_{i}}$ and $\ln \bar{p}_{i}$ values are summed and then multiplied, and the results are added. Next, the $\operatorname{\operatorname {ln}} p_{i}$ value is calculated. Again, as in the formula, this process should be done for all species. As a result, Shannon-Wiener index value $H^{\prime}$ is obtained. This value should be calculated for all sample areas, not just one sample area. 
All sample areas should be studied in the same way for the balance value, $E$. In the formula, $E$ is used as the exponential expression/species richness of the Shannon-Wiener value. In the next step, it is necessary to obtain the $\ln E / \ln S$ value so that the SHE analysis graph can be interpreted more easily. Those close to 0 in the last value graphed, close to 1 in the equality value, and in the $H$ value, the degree of importance increases as the value increases. Attention should be paid to the high diversity value in the sample areas and the balanced distribution of species. The $E$ value being close to 1 indicates that the distribution in the proportional values between species within the community is close [14, $8,20,23$, $31]$.

$S=\sum_{i}^{S} S_{i}$

The formulas used in the SHE analysis are given below [23].

$p_{i}=x_{i} / \sum_{i}^{S} x_{i}$

$H=-\sum p_{i} \ln p_{i}$

$E=e^{H} / S$

Where $\sqrt{S}$ is the number of species, $\sqrt{H}$ is Shannon index and $\bar{E}$ is evenness. $\bar{x}_{i}$ represents the abundance of $\bar{i}$. species and $p_{i}$, the relative value of the $i$. species $\left(p_{i}=x_{i} / \sum_{i}^{S} x_{i}\right)$. SHE analysis was performed using BİÇEB (A software for Estimating Biodiversity Components) program [24].

Table 1: Example of calculations for each sample area ÖA1 (Sample Area 1) value table

\begin{tabular}{|l|c|l|l|l|}
\hline Species & $\begin{array}{c}\text { Abundance } \\
\text { Value }\left(\sqrt{x_{i}}\right)\end{array}$ & $\bar{p}_{i}$ & $\ln \left(\bar{p}_{i}\right)$ & $-\sqrt{i} \times \ln \left(p_{i}\right)$ \\
\hline AbiCip & 2 & 0,068965517 & $-2,6741486$ & 0,184424045 \\
\hline AstrSp & 2 & 0,068965517 & $-2,6741486$ & 0,184424045 \\
\hline BerCra & 2 & 0,068965517 & $-2,6741486$ & 0,184424045 \\
\hline CedLib & 4 & 0,137931034 & $-1,9810015$ & 0,273241582 \\
\hline CliVul & 1 & 0,034482759 & $-3,3672958$ & 0,116113649 \\
\hline CniSio & 2 & 0,068965517 & $-2,6741486$ & 0,184424045 \\
\hline ColCil & 2 & 0,068965517 & $-2,6741486$ & 0,184424045 \\
\hline DapOle & 2 & 0,068965517 & $-2,6741486$ & 0,184424045 \\
\hline EupKot & 2 & 0,068965517 & $-2,6741486$ & 0,184424045 \\
\hline PicPau & 1 & 0,034482759 & $-3,3672958$ & 0,116113649 \\
\hline PinNig & 4 & 0,137931034 & $-1,9810015$ & 0,273241582 \\
\hline RosPul & 2 & 0,068965517 & $-2,6741486$ & 0,184424045 \\
\hline ThySin & 1 & 0,034482759 & $-3,3672958$ & 0,116113649 \\
\hline VerbSp & 2 & 0,068965517 & $-2,6741486$ & 0,184424045 \\
\hline
\end{tabular}

The essence of SHE analysis is the relationship between $S$ (species richness), $H$ (diversity as measured by the Shannon index), and $E$ (evenness). The manner in which this relationship changes as a function of sample size can be remarkably informative. Like the estimation of species richness, this approach makes use of accumulated samples [19]. The high value of $H$, which expresses diversity, and $E$, which indicates the proportionally homogeneous distribution of species in the community, indicates that there is solidarity among the species in the community and, accordingly, the resistance against natural or human risks from outside increases. $H$ value gives diversity, whereas equality, $E$, only shows the homogeneity of proportional distribution of species within the community. If the $E$ value is high in the parts with high diversity, it can be said that the solidarity between species within the community and, accordingly, the resistance against natural or human risks from outside increases. Species richness, $S$, is the simplest species diversity parameter. Since it does not include the proportional or abundance values of the species, the $H$ value in the SHE analysis completes this part and provides a holistic interpretation $[19,23]$.

\section{Results}

According to the results of the SHE analysis applied to the Karg1 Stream valley, the $H$ value, that is, the areas with the highest diversity value, are ÖA18A, ÖA20A, ÖA8A, ÖA9A, ÖA11A, ÖA5A, ÖA12A, ÖA14A, and ÖA10A, respectively. The sample area ÖA17C, on the other hand, was calculated as the place with the lowest plant species diversity. Sample areas coded as ÖA15C, ÖA1D, ÖA17B, ÖA17D, ÖA3C, ÖA3B, ÖA1B are also areas with low species diversity. Sample areas where the proportional distribution of the species is homogeneous according to the results of the 
$E$ value; ÖA4D, ÖA2C, ÖA4B, ÖA20A, ÖA20B, ÖA20C, and ÖA5B. The areas where plant species are less evenly distributed are ÖA10D, ÖA15A, ÖA17A, ÖA16A, ÖA17B (Figure 2).

ÖA20A has the highest $H$ value among the sample areas. It also shows a homogeneous distribution of species and, stands out with its diversity and resistance to threats in the Karg1 Stream valley. According to $\ln E / \ln S$ comparisons, places with a balanced distribution in areas with high species diversity in the Karg1 Stream valley, as in ÖA20, are generally important places in terms of ecosystem continuity, dynamism and strength. Another important point is that although the species diversity is relatively high in ÖA10A, the $\ln E / \ln S$ value also decreases due to the low stability value. As mentioned before, it is very difficult for the natural environment to protect itself, as the destruction of such areas will occur much more easily. The situation is different in ÖA15A, which has another low value. Here, it gives low value in terms of conservation value, since both species diversity and stability are low. The situation is similar in ÖA17A; both species diversity and stability are low.

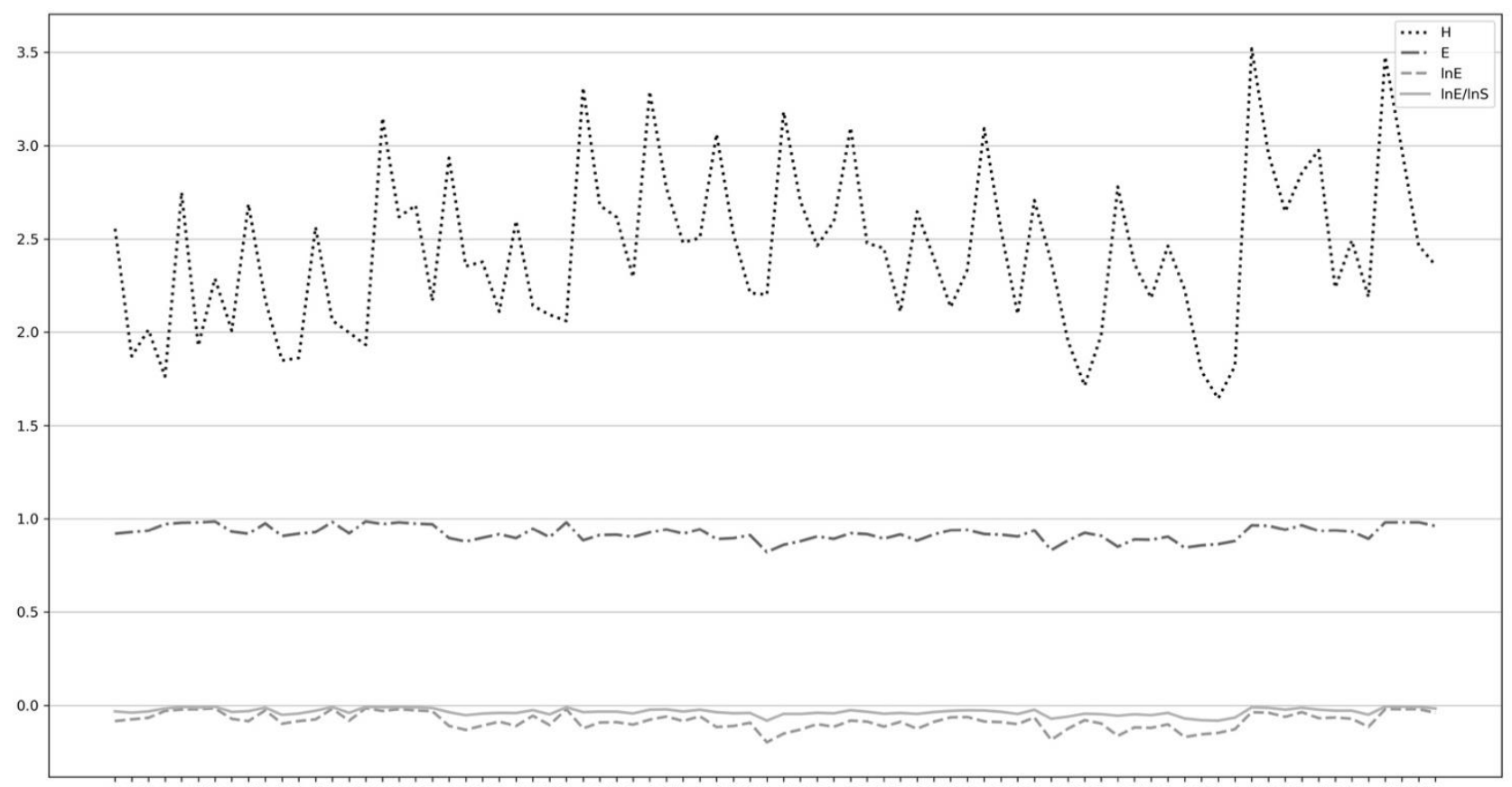

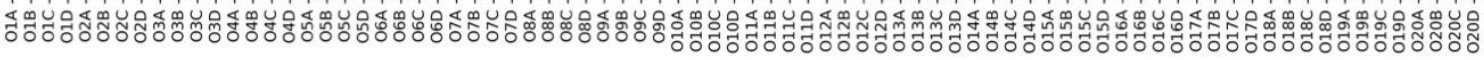

Figure 2: Karg1 Stream valley SHE analysis result graph

According to the results of the SHE analysis carried out on the sample areas determined in the Karpuz Stream valley, the area with the highest species diversity is ÖA3A. It was followed by ÖA5B and ÖA1A. The areas with the lowest species diversity are ÖA7B, ÖA11D, and ÖA10D. If the value of $E$ is equality, all 6 and 3 coded sample areas are the places where the species are most evenly distributed. The places with the least equal distribution are ÖA1A, ÖA19A, ÖA20A, ÖA20B and ÖA20D (Figure 3). As in Karg1 Stream, there is no sample area where both species diversity and equality are balanced. Therefore, $\overparen{\ln E / \ln S}$ results were interpreted differently and instead of focusing on areas with the highest species richness, sample areas with average richness but also relatively high stability ratio was more apparent in calculation. Thus, all of the sample areas numbered 6 were determined as areas to be protected in the Karpuz Stream valley. 


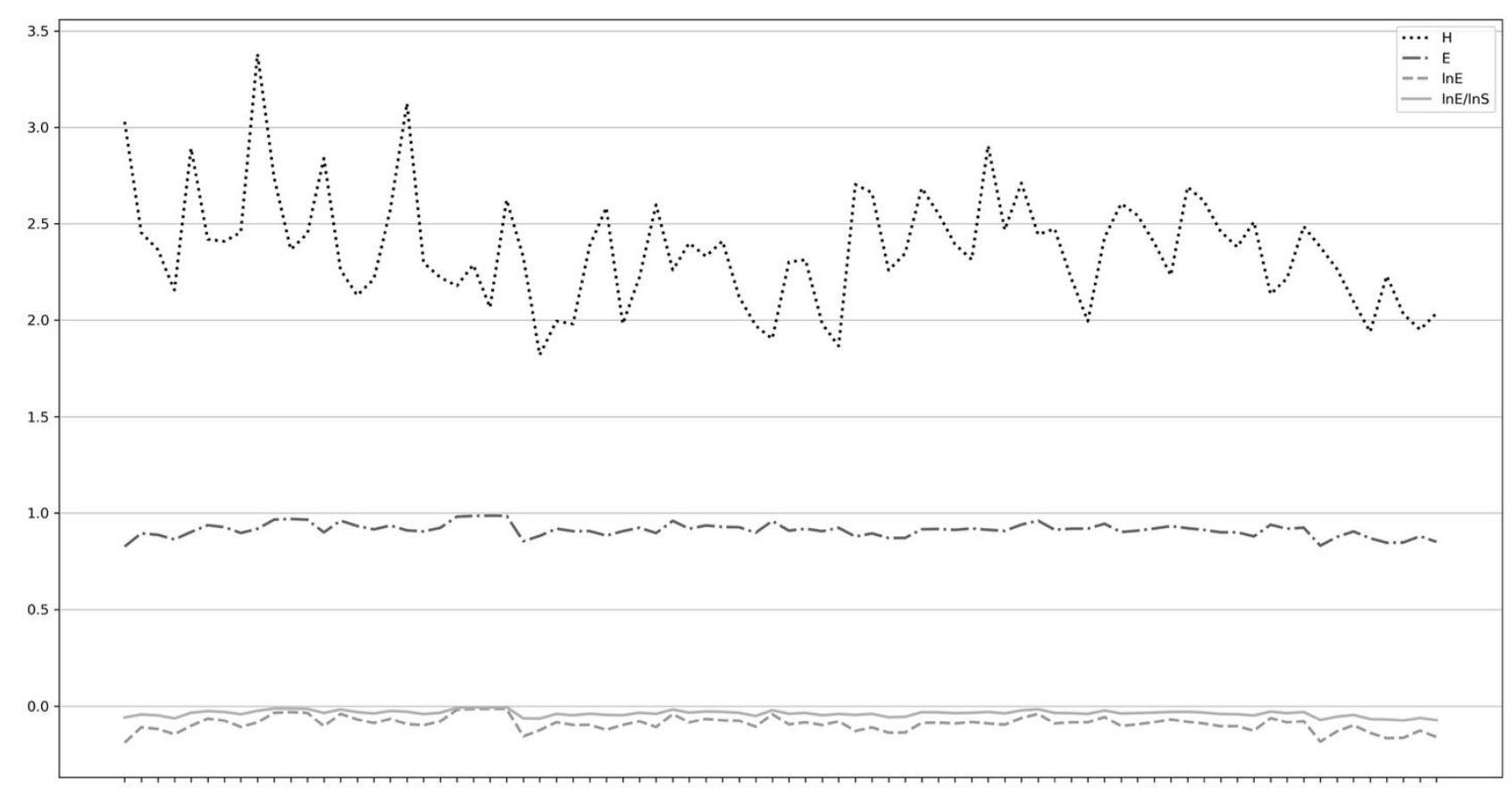

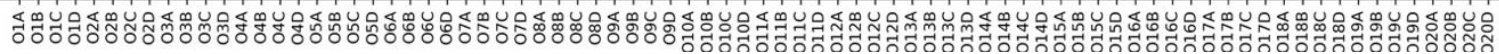
Figure 3: Karpuz Stream valley SHE analysis result graph

\section{Discussion and Conclusions}

Conservation of biodiversity is one of the most important goals in ecosystem management $[28,26]$. There is a great deal of literature on biodiversity. Most of these studies argue that biodiversity has a unique value and that this value is not a concept that can be given by humans. Although it is not possible to protect biodiversity altogether, preventing biodiversity loss is the most important challenge in conservation [18]. For this reason, it is very important to determine the protection priority of certain regions, especially in areas rich in species (rare species, threatened species or a combination of these features). It has been observed that biodiversity studies at large geographical scales are more beneficial for conservation planning of "hotspots" where species diversity and endemism are high, while small scales provide relatively limited benefit $[9,25,28]$. However, identifying hotspots on a large scale depends on local species richness. The Mediterranean Region, which is quite remarkable in terms of vegetation as a whole and has high biodiversity, is one of the hotspots that are extraordinarily rich in endemic species but at the same time is in danger of habitat destruction [11, 4].

It is known that there are 26 rare taxa across the country in the Karg1 Stream valley, which is one of the valleys covered in the study [12]. The coastal areas of the region, defined as the Taurus Mountains Plant Diversity Center (SWA No. 15), are under the pressure of intense tourism activities. Behind the coasts, agriculture and animal husbandry activities come to the fore. Apart from these human factors, forest fires increase in the region with the effect of high temperatures in the summer months. Therefore, as in the entire Mediterranean Basin, the study area is one of the areas where the effects of human activities on the environment are quite high [1]. Coasts, which are used for purposes such as resource use, industrial establishments, tourism and recreation, also witness uses for conservation rather than consumption for the protection of biodiversity and important natural areas [5].

The biodiversity of the valleys was measured by using alpha, beta and gamma diversity analyzes in order to determine the priority areas for protection in the Kargı and Karpuz Stream valleys, whose natural vegetation is gradually changing due to human factors [2].

In this study, the areas where plant species are distributed homogeneously or heterogeneously and areas that are more resistant to external factors were determined by, SHE analysis. In this way, ecosystems that are relatively sensitive and valuable in terms of plant species diversity in the river valleys have been identified, and an example has been set for the selection of priority areas in conservation planning.

The higher the diversity values in the SHE analysis, which gives the opportunity to comment on the graph, the more valuable the ecosystem. By determining a threshold in the data obtained as a result of the analysis, areas with priority protection can be determined by ignoring the sample areas below this threshold (for example, areas above 2.5). In the next stage, how to apply a conservation application in these areas is another matter of discussion. For instance, the area to be protected can be turned and left to be observed over time, or protection measures can be taken in certain areas such as in-situ or ex-situ. High species diversity in a community can stabilize the ecosystem when environmental changes occur, by compensating for the increased abundance of one species to compensate for the decreased abundance of another. 
Therefore, measures can be taken to prevent species loss by focusing more on the area with low stability in two areas where species diversity is high. The results obtained with the SHE analysis focus not only on the species diversity in the sample areas but also on the high stability. When these two parameters are close to each other, it indicates the sustainability of the conservation in the area. If the diversity is high but the distribution of the species is not balanced, the ecosystem becomes vulnerable, making it difficult to protect the area. When the stability rate is high, but the species diversity is low, this time the biodiversity rate decreases [30, 21, 29, 23].

Karg1 Stream and Karpuz Stream valley do not currently have an official protection status as stated before. Alpha diversity calculations were made with the inventory study carried out in these valleys. The results were reinterpreted with the SHE analysis and plant species diversity and stability in the sample areas were determined. In Karg1 Stream, ÖA20 has been determined as a priority area to be protected; Although species diversity was high in ÖA10A, it was left behind due to its low stability value. In the Karpuz Stream, on the other hand, since there is no area where both species diversity and balanced distribution are high, 6 and 3 coded sample areas with close diversity and balance ratios were suggested as priority protection zones. As a result of the analysis obtained in this direction, it was emphasized that plant species diversity at the scale of river valleys is not sufficient on its own in the determination of priority areas for protection and that the balance in species distribution is a very important issue to be considered. Thus, this study represents the necessity of interpreting the results of alpha species diversity calculations by blending them with the SHE analysis, and how plant species diversity should be interpreted so that decision-makers can make clearer conservation plans in the future.

\section{Acknowledgement}

The authors admit special thanks to TÜBITAK for the financial support and Prof. Dr. Kürşad Özkan for organizing the "2237-A Biological Diversity Measurement Processes-Inventory, Data Transfer and Computing Techniques" scientific event and to the reviewers for their constructive criticism.

\section{References}

[1] Akkurt Gümüş, S. (2020). Manavgat Çayı ve Dim Çayı Arasının Bitki Örtüsü ve Biyoçeşitlilik Analizleri. Istanbul University, Social Sciences Institute, Unpublished Doctoral Dissertation.

[2] Akkurt Gümüş, S. \& Avcı, M. (2020). Biyoçeşitlilik indisleri kullanılarak öncelikli koruma alanı seçimine bir örnek: Kargı Çayı ve Karpuz Çayı vadileri- (Akdeniz Bölgesi-Türkiye)-Primary conservation area selection with biodiversity indices: A case study on the Kargı and Karpuz river valleys (Mediterranean Region-Turkey). Coğrafya Dergisi, 41, 1-18.

[3] Anderson, M.J., Crist, T.O., Chase, J.M., Vellend, M., Inouye, B.D., Freestone, A.L. Sanders, N.J., Cornwell, H.V., Comita, L.Z., Davies, K.F., Harrison, S.P., Kraft, N.J.B., Stegen, J.C. \& Swenson, N.G. (2011). Navigating the multiple meanings of $\beta$-diversity: a roadmap for the practising ecologist, Ecology Letters, 14, 19-28.

[4] Avc1, M. (2018). Ekosistem Coğrafyası. İstanbul Üniversitesi Açık ve Uzaktan Eğitim Fakültesi, İstanbul.

[5] Avcı, S. (2017). Kıyı alanlarının kullanımında beşerî faktörler. Yasal ve Bilimsel Boyutlarıyla Klyı (Ed: Turoğlu, H., Yiğitbaşığlu, H.), 117-146, Jeomorfoloji Derneği, İstanbul.

[6] Buzas, M.A. \& Hayek, L.A.C. (1996) Biodiversity resolution: an integrated approach. Biodiversity Letters, 3, 4043.

[7] Buzas, M.A. \& Hayek, L.A.C. (1998). SHE analysis for biofacies indentification. Journal of Foraminiferal Research, 28 (3), 233-239.

[8] Buzas, M.A. \& Hayek, L.A.C. (2005). On Richness and Evenness within and between Communities. Paleobiology, 31(2), 199-220.

[9] Cadotte, M.W. \& Tucker, C.M. (2018). Difficult decisions: Strategies for conservation prioritization when taxonomic, phylogenetic and functional diversity are not spatially congruent. Biological Conservation, 225, 128133.

[10] Cardoso, P., Rigal, R., Carvalho, J.C., Fortelius, M., Borges, P.A.V., Podani, J. \& Schmera, D. (2014). Partitioning taxon, phylogenetic and functional beta diversity into replacement and richness difference components. Journal of Biogeography, 41 (4), 749-761.

[11] Cuttelod, A., García, N., Abdul Malak, D., Temple, H. \& Katariya, V. (2008). The Mediterranean: a biodiversity hotspot under threat (Eds. Vié, J.C., Hilton-Taylor, C. \& Stuart, S.N.). The 2008 Review of The IUCN Red List of Threatened Species. IUCN Gland, Switzerland.

[12] Duman, H. (2010). Kargı Çay Vadisi. Important Plant Areas, 122 Key Turkish Botanical Sites (Eds. Özhatay, N., Byfield, A., Atay, S.), 227-228, WWF Türkiye (Doğal Hayatı Koruma Vakfi) İstanbul.

[13] Hayek, L.A.C. \& Buzas, M.A. (1997) Surveying Natural Populations. Columbia University Press, New York.

[14] Hayek, L.C. \& Buzas, M.A. (1998). SHE analysis: An integrated approach to the analysis of forest biodiversity, Forest Biodiversity Research, Monitoring and Modeling (Eds. Dallmeier, F. and Comiskey, J.), 311-321, UNESCO and Parthenon Publishing Group, Paris.

[15] Jost, L. (2007). Partitioning diversity into independent alpha and beta components. Ecology, 88 (10), 2427-2439. 
[16] Jurasinski, G., Retzer, V. \& Beierkuhnlein, C. (2009). Inventory, differentiation, and proportional diversity: A consistent terminology for quantifying species diversity. Oecologia, 159, 15-26.

[17] Kurt, B. (2006). Karg1 Çay Vadisi, Türkiye’nin Önemli Doğa Alanlarl (Eds. Eken, G., Bozdoğan, M., İsfendiyaroğlu, S., Kılıç, D.T. \& Lise, Y.), 366-367, Doğa Derneği Ankara.

[18] Lang, S., Mairota, P., Pernkopf, L. \& Schioppa, E.P. (2015). Earth observation for habitat mapping and biodiversity monitoring, International Journal of Applied Earth Observation and Geoinformation, 37, 1-6.

[19] Magurran, A.E. (2004). Measuring Biological Diversity. Blackwell Science Ltd. USA.

[20] Mana, D. (2005). A test application of the SHE method as a biostratigraphical parameter. Geo.Alp, 2, 99-106.

[21] Maxted, N. (2001). Ex-situ, In-situ Conservation. Encyclopedia of Biodiversity, 683-695.

[22] Osterman, L.E., Buzas, M.A. \& Hayek, L.C. (2002). SHE Analysis for Biozonation of Benthic Foraminiferal Assemblages from Western Arctic Ocean. Palaios, 17 (3), 297-303.

[23] Özkan, K. (2016). Biyolojik Çeşitlilik Bileşenleri ( $\alpha, \beta$ ve $\gamma$ ) Nasıl Ölçülür?. Süleyman Demirel Üniversitesi Yayınevi, Isparta.

[24] Özkan, K., Küçüksille, E.U., Mert, A., Gülsoy, S., Süel, H. and Başar, M. (2020). A Software for Estimating Biodiversity Components (BİÇEB), Turkish Journal of Forestry, 21(3), 344-348.

[25] Pearce, D.W. (2003). The value of biodiversity. Microbial Diversity and Bioprospecting (Ed: A.T. Bull), Wiley Online Library, https://doi.org/10.1128/9781555817770.ch44.

[26] Reddy, C.S. (2021). Remote sensing of biodiversity: what to measure and monitor from space to species? Biodiversity and Conservation https://doi.org/10.1007/s10531-021-02216-5.

[27] Reid, W.V. (1998). Biodiversity hotspots. Trends in Ecology and Evolution, 13 (7), 275-280.

[28] Sloan, S., Jenkins, C.N., Joppa, L.N., Gaveau, D.L. \& Laurance W.F. (2014). Remaining natural vegetation in the global biodiversity hotspots. Biological and Conservations, 177, 12-24.

[29] Thormann, I., Dulloo, M.E. \& Engels, J.M.M. (2006). Techniques for Ex Situ Plant Conservation. Plant Conservation Genetics (Ed. Henry, R.J.), 7-36, The Haworth Press, Inc.

[30] Yachi, S. \& Loreau, M. (1999). Biodiversity and Ecosystem Functioning in a Fluctuating Environment: The Insurance Hypothesis. Proceedings of the National Academy of Sciences, 96, 1463-1468.

[31] Yazgi, D. \& Yilmaz, T. (2017). Employing SHE Analysis Method for Evaluating Landscape Diversity, Biological Diversity and Conservation, 10 (3), 65-72. 